\title{
Startup Company Valuation: The State of Art and Future Trends
}

\author{
Damiano Montani ${ }^{1}$, Daniele Gervasio ${ }^{1} \&$ Andrea Pulcini $^{1}$ \\ ${ }^{1}$ University of Bergamo, Bergamo, Italy \\ Correspondence: Damiano Montani, University of Bergamo, Bergamo, Italy. \\ Received: May 29, 2020 \\ Accepted: August 4, $2020 \quad$ Online Published: August 12, 2020 \\ doi:10.5539/ibr.v13n9p31 \\ URL: https://doi.org/10.5539/ibr.v13n9p31
}

\begin{abstract}
The aim of this conceptual article is to present a systematic literature review about the most used and innovative startup valuation methods to define the state of art and future trends on this important topic.

Because of the particular features of early-stage companies, it is not easy to find an adequate method to assess their value. Traditional valuation methods are unsuitable for startups. Therefore, over time, academic literature and experienced investors created alternative and innovative valuation models. We analysed the main models, outlining the advantages and limits for each one.

The results of our analysis show that there is currently no "perfect" method to assess a startup's value. Each model discussed has significant limits, and the possibilities for improvement are many. We are witnessing a gradual withdrawal from more arbitrary valuation models, and consciousness is growing towards the idea that to better assess startup's value, it is necessary to consider three aspects: attention to future forecasts instead of past data, using probability to consider different scenarios, and understanding of and attention to the specific business model of the startup rather than data on comparable companies in the market. Currently, none of the discussed methods integrates these three features harmoniously.

We expect that in the near future, the academic literature will develop new valuation methods (or will perfect existing ones) that should consider the three characteristics mentioned previously. In this way, it would be possible to create a more suitable method to assess a startup's value, i.e., a method to reduce uncertainty and that better represents the startup's value and makes startup company valuation more reliable.
\end{abstract}

Keywords: innovative startup valuation methods, literature review, startup's value, traditional company valuation methods, venture capital

\section{Introduction}

The aim of this conceptual article is to present a systematic literature review about the most used and innovative startup valuation methods to define the state of art and future trends on this important topic.

First, we have to define a startup company. In the literature, there is not a unanimous definition. Birley \& Westhead (1994) defined startups as small, new, independent businesses established by individuals to be self-employed. Other authors (Granlund et al., 2005) developed a startup definition considering fast growth or already fast-growing firms that operate in information and communications technology businesses and the biotech (life sciences) industry (also called New Economy Firms, NEF). David \& Foster (2005) considered a startup to be a company with these characteristics: (1) minimum of 50 and maximum of 150 employees, (2) less than ten years old, (3) independent, and (4) in a limited geographic area. For Kollmann et al. (2016), startup companies must have three features: be younger than 10 years old, have highly innovative technologies and/or business models and have (or strive for) significant employee and/or sales growth. A famous entrepreneur, Steve Blank, defined a startup as a temporary organization in search of a scalable, repeatable, profitable business model (Blank, 2020). Summarizing, although there are different definitions of startups, we can say that a basic and commonly acceptable definition of startup was given by Kolvereid \& Isaksen (2006): "new businesses which are started from scratch".

The importance of correct startup valuation is directly related to the importance of this kind of company in today's economy (Akkaya, 2020). In 2017 and 2018, the global startup economy generated 2.8 trillion dollars in economic value. This figure was a twenty per cent increase from the prior two-year period (Stangler, 2019). In addition, startups are the main actors promoting technological innovation (Cho et al., 2020). Moreover, startups 
contribute dramatically to job creation. On average, across OECD countries and over years, young firms account for approximately $20 \%$ of employment but create almost half of new jobs. We specify that data about job creation are characterized by a fair degree of heterogeneity: only a tiny fraction of startups substantially contribute to job creation, whereas the majority either fail in the first years of the activity or remain very small (Calvino et al., 2016).

Therefore, taking into consideration the spread and importance of startups to the economy, it is important to understand correct methods for measuring their value (Sander \& Kõomägi, 2007).

Over time, it has become evident that traditional evaluation methods (cost approach, income approach, market approach) are not adequate to assess startup's value. Therefore, academic literature and practitioners created alternative methods that should be more adequate for startup valuation.

In this paper, we analyse the most used and important of these innovative valuation methods using a systematic literature review, outlining advantages and limits for each and defining the state of art and future trends on this topic.

\section{Method}

The present article contributes to previous research by summarizing and critically investigating the research taken on the topic of startup valuation, which is one way to contribute conceptually to the literature (Gummerus, 2013). This literature review aims to comprehensively synthesize research that bears on a particular question using organized, transparent, and replicable procedures at each step in the process (Littell, 2008) to identify, in our case, the contributions in the field of the startup company valuation.

According to Fink (2019), we followed four steps for this systematic review. In the first step, we selected the research question, databases, websites and appropriate research terms. The research question was rather broad: "What are better methods to assess startup value today?". To search the literature, we chose numerous variants of keywords focused on startup valuation. The databases searched were those provided by major publishers and by library services. We also used Google Scholar to identify other relevant material, such as conference proceedings and similar publications. The second step is the application of practical screening criteria. We considered refereed academic papers, books, research reports, conference proceedings and practitioner-oriented contributions from professional journals written in English without a time restriction. The third step is the application of methodological screening criteria. We considered, for each source, bibliographic data (authors, year, title, etc.), the background of the publication (is it theoretical/conceptual, empirical or practical oriented source?), and the focus and content of the publication. The last step consists of expositions of our analysis results.

\section{Literature review}

\subsection{The Reasons Why Traditional Valuation Methods for Companies Are not Adequate to Assess the Startup Value}

Generally, the traditional valuation methods for firms (cost approach, income approach and market approach) do not work for startups (Dehghan-Eshratabad \& Albadvi, 2018).

The main issue that limits the use of traditional valuation methods is the absence of typical information they need to work correctly. There are no data on past revenue or cash flow (the company is newly started), often there are not market data (absence of comparable firms/transactions), companies' assets are intangible and difficult to evaluate in an objective way (Dusatkova \& Zinecker, 2016).

The cost approach (represented primarily by the capital method) is based on an analytic valuation of the current value of assets and liabilities (Fernandez, 2007). It is static because it does not take into account company evolution in the future (De Olivera \& Zotes, 2018). Generally, the cost approach is the least suitable to assess the economic capital of startups. Indeed, the startups' value is in the idea created by the founders and its subsequent development, not in the assets, because the newly started company has, usually, very few tangible assets and is undercapitalized (Krishna et al., 2016). However, as stated by Beaton (2010), the cost approach could be useful to assess the value of startups only if the valuation is made in the embryonic stage when it is impossible to make reliable projections for the future, and the value of the startup could be approximated by the amount invested by the founders.

The income approach is based on the company's value and ability to generate prospective revenues/cash flows using three logical steps: (1) set the timeframe for the flow analysis, (2) assess the "normal expected" income/cash flows, and (3) set the correct discount rate. The discounted cash flow (DCF) method could be useful 
to assess the economic capital of firms rapidly growing that have not yet reached a level of operational maturity (IVSC, 2012; Laitinen, 2019). Nevertheless, there are many problems in the application of the DCF (and, in general, the income approach) to measure the value of startups (Sander \& Kõomägi, 2007). It is based on a set of fixed assumptions related to project payoff, but the payoff is uncertain and probabilistic (Shestakov, 2015). Moreover, especially for young companies, the terminal value (TV) is dramatically important (Reis \& Augusto, 2013). It can represent ninety per cent of the total value of the company, but the definition of the TV for a startup is much more complex because it is impossible to consistently establish the following elements (Damodaran, 2016): if, when and how the company will grow. Another relevant problem is the definition of the discount rate for young companies (Hoseini \& Moradi Esfanjani, 2019). Traditional models, such as CAPM, are inadequate because they determine the discount rate considering sector characteristics and the historical background of the company, but for startups, it is impossible to extrapolate back past returns, to get the beta of the firm, and often startup companies have features that are very different from other companies in the sector. Moreover, traditional models assume uniform market risk over time, but risk changes over time, especially for newly created companies. In addition, traditional approaches to assessing the discount rate concentrate on market risk, whereas the main risk for startups is the firm's specific risk (Steffens \& Douglas, 2007).

With the market approach, the company's value is based on market multiples and refers to comparable multiples or transactions in the stock market. This approach is difficult to implement with newly created companies because multiples are generally based on profits or revenues, but in young companies these economic variables are often negative (usually startups record losses, not profits, and at the beginning revenues are very low). In addition, it is almost impossible to find comparable data in the market as every company has specific and not replicable features. Furthermore, in general, market data available are for mature companies, not early-stage firms (Damodaran, 2009).

A fundamental assumption for traditional valuation methods is the efficiency of the capital market (Stankevičienė \& Žinytė, 2011). This hypothesis could approach reality in the case of public capital market, where there are legal regulations that require a public company to show all relevant information to stakeholders (Ge et al., 2005). The situation is different in the private capital market where information asymmetry is higher. This situation can create evaluative inefficiency in the sense that prices in the market do not reflect the real value of companies. Firms are tempted to behave opportunistically, giving only partial or distorted information. On the other hand, investors protect themselves by increasing their caution in evaluating these firms. These elements create resource allocation that is far from Pareto optimal, and it generates an information reliability issue, which may explain why startups have difficulties getting funding (Houben, 2002; Nofsinger \& Wang, 2011).

\subsection{Alternative Methods for Startup Valuation Discussed in the Academic Literature}

First, it should be remembered that for any company valuation, it is essential to get adequate information (Sievers et al., 2013; Schmidlin, 2014) and to proceed to a correct contextualization of the business reality (Montani et al., 2018). As outlined by Black (2003), the company's value depends on two elements: current activities and development opportunities. For the nature of information, we distinguish between financial and non-financial information (Flöstrand \& Ström, 2006). Information about growth opportunities and non-financial information (Shevlin, 1996; Ho, 2016) is of great importance for startup valuation (Köhn, 2018). Amit et al. (1990) showed that management team skills were crucial elements to successful startup companies. Indeed, this non-financial information is considered by many startup valuation methods (Miloud et al., 2012; Reverte et al. 2016).

In the remainder of this article, we discuss the most innovative and commonly used startup valuation methods and outline their advantages and limits.

\subsubsection{The Real Option Method}

The real option method (ROM) comes from the financial option theory created by Black \& Scholes (1973), and later it found applications in other economic areas (Andalib et al., 2018). According to this model, managers' choices can be similar to a financial option (put or call). Investment decisions made by managers tend to be incremental and sequential in nature, and the decider can continue or leave a path started. Decisions are made in an uncertain environment, and uncertainty is reduced as you get more information. Therefore, the ROM is able to capture management's flexibility to adapt and revise later decisions in response to unexpected market developments (Wardani \& Fujiwara, 2018). As outlined by previous studies, managerial decision-making skills have to be valued to reach a correct valuation (Mathews, 2009; Fazekas \& Becsky-Nagy, 2015; Cong, 2017). Consider, for example, a company that has identified an opportunity (an option) that requires investment today and additional investment in six months (the exercise price). In six months, if the opportunity looks promising, 
which means the net present value is higher than the exercise price of the option, the option is exercised and the project goes ahead. If the project does not look promising, the option is not used and the only loss is the price of the option paid (Frykman \& Tolleryd, 2012).

With the ROM, the enterprise value is defined in the following manner (Frykman \& Tolleryd, 2012):

Enterprise Value = Value of existing operation + Value of the company portfolio of real options

The ROM could be useful to assess startup value because it considers the strategic flexibility contained in investment decisions (Smit \& Trigeorgis, 2012).

However, it is wrong to think that this model is always adequate to assess a startup's value. It has critical issues too (Milanesi et al., 2013). In particular, to date, simple, reliable and easily accessible models to assess the value of a real option does not exist. As stated by Frykman \& Tolleryd (2012), the ROM is more a conceptual way to think about business projects - real option thinking - than a real evaluation technique.

\subsubsection{The Venture Capital Method}

The venture capital method (VCM) originated in the work of Sahlman \& Scherlis (1987).

The VCM is inspired by the DCF method (Keeley et al., 1996). It assesses a company's value basing on the net present value of future cash flows in the most likely scenario (success scenario), with a definite time-horizon and an interest rate that reflects the high risk of investment (Smith et al., 2011). Compared to the DCF, the VCM takes into account the riskiness of the business in its valuation. The VCM calculates a startup's value by assessing future cash flows using company comparables and a market multiple approach. Then, the startup's value is discounted on the investment date using a very high discount rate.

The formula showing the pre-money value (Note 1) is the following (Keeley et al., 1996):

$$
\text { Net Present Value (NPV) pre-money }=\frac{P_{T, V C}}{\prod_{t=1}^{T}\left(1+R_{t, V C}\right)}-\sum_{t=1}^{T} \frac{I_{t, V C}}{\prod_{t=1}^{t}\left(1+R_{\tau, V C}\right)}-I_{0, V C}
$$

Where:

$\mathrm{P}_{\mathrm{T}, \mathrm{VC}}=$ venture capitalist's estimate of company value at $\mathrm{T}$

$\mathrm{I}_{\mathrm{t}, \mathrm{VC}}=$ venture capitalist's estimate of additional investment required at time $\mathrm{t}$

$\mathrm{R}_{\mathrm{t}, \mathrm{VC}}=$ venture capitalist's one-year discount rate to discount from $\mathrm{t}$ to $\mathrm{t}-1$

$\mathrm{I}_{0, \mathrm{VC}}=$ net present value of initial investment

The method is developed in three phases:

- The first step is assessing the expected cash flows (Damodaran, 2009). The time horizon is from two to five years. Generally, the time horizon coincides with the moment when the venture capitalist considers selling or making the startup public (Sammut, 2012). The future projection of cash flows is based on a single scenario that one considers more realistic (Goldman, 2008). The value at the end of the time horizon (Terminal Value) is assessed, with an equity side approach, by multiplying expected cash flows with the equity multiple (e.g., $\mathrm{P} / \mathrm{E}$ ), which is defined based on market prices given to comparable companies.

- The terminal value as determined is discounted by a very high discount rate (Bhagat, 2014) that represents the rate of return requested by the venture capitalist to get the net present value (NPV).

- In the end, in return for equity invested, the venture capitalists get an equity share (Pepis et al., 2018). To establish it, the company's post-money value has to be calculated, and it is equal to the sum of the NPV pre-money and investment amount given by the venture capitalist (Visconti, 2020)

$$
N P V_{\text {post money }}=N P V_{\text {pre money }}+\text { Investment Amount }\left(I_{0, v c}\right)
$$

The equity share that has to be given to the venture capitalist is determined by dividing the capital increase with the post-money value (Damodaran, 2009). In summary, the venture capitalist that invests $\mathrm{I}_{0, \mathrm{vC}}$ wants in return shares with a value of (at least):

$$
I_{0, v c} / N P V_{\text {post money }}
$$

The VCM is a commonly used method to assess a startup's value, especially in the pre-revenue stage (Payne, 2011a). However, the VCM also has limits. One of the most important is the discount rate used (Goldenberg \& Goldenberg, 2009). Some authors outlined that it is not correct to incorporate the default risk of the company into a high rate determined in an arbitrary way (Steffens \& Douglas, 2007). Moreover, incorporating default risk in the discount rate means considering the first as constant over time, during the entire company life cycle, but 
this assumption is an unrealistic assumption (Damodaran, 2009). Another VCM limit is the inability to consider many scenarios.

It should be noted that there are also some "modified" venture capital methods (Babiarz, 2016), but they are not well-known and little used.

\subsubsection{The First Chicago Method}

The name of this method comes from the first fund that used it, the Chicago corporation. It is a model that combines elements of the expected results approach and the market-oriented approach (Hashemi, 2015).

The first Chicago method (FCM) is an evolution of the VCM, from which it differs by using a lower discount rate and the terminal value is substituted by the net present value of investment calculated as the average of the startup's value in different scenarios (Majercakova \& Mittelman, 2018).

The peculiarity of the FCM lies in considering three possible scenarios (Achleitner \& Lutz, 2005): the "best guess", i.e., the most likely situation (generally, an intermediate case), the "best scenario" (optimistic) and the "worst scenario" (pessimistic). A probability of occurrence is assigned to every scenario that is subjective (Steffens \& Douglas, 2007). In summary, the FCM considers different scenarios, assesses the probability of occurrence for each one, and it calculates the net present value of expected cash flows weighted by probability, using a lower discount rate than that used by the VCM. In analytical terms, a startup's value, for each scenario, is composed of two elements. The first element is the net present value of the company when it will be sold, and the second element is the present value of cash flows until the moment of planned divestment (Babiarz, 2016):

$$
P V_{i}=\sum_{t=1}^{h} \frac{C F_{t}^{i}}{(1+r)^{t}}+\frac{T V_{i}}{(1+r)^{h}} \rightarrow P V=\sum_{i=1}^{3} p_{i} P V_{i}
$$

Where:

$\mathrm{i}=$ scenario index;

$\mathrm{h}=$ time to exit

$\mathrm{PV}=$ present value

$\mathrm{CF}=$ cash flows in period $\mathrm{t}$

$\mathrm{TV}=$ terminal value

The method is developed in three phases:

- In the beginning, it is necessary to define the three scenarios, preparing a financial forecast for each one. Generally, the optimistic scenario provides for high sales growth, the intermediate scenario includes what the forecaster expects, and the worst scenario considers default by the company.

- In the second phase, the cost of divestiture in each scenario is calculated using market multiples (comparable transactions selected considering the following factors: type of business, geographical location, and the phase of the company life cycle). It is the terminal value at the moment of divestment.

- In the end, there is a determination of the startup's value. It is equal to the sum of the net present value of each scenario (the terminal value plus expected cash flows until the moment of planned divestment) weighted by the probability that each scenario occurs (Hashemi, 2015).

In contrast with the VCM, the FCM has the merit of considering more scenarios, allowing more prudent and realistic valuations. An additional advantage of this method is the identification of some specific risks associated with startups. However, the FCM also has limits. It does not take into account potential changes in the situation, and it is most suitable for startups that already generate revenue (Demyanova, 2018).

\subsubsection{Modified DCF Method}

Different authors argue that the DCF method, with appropriate corrections, could be very useful for assessing a startup's value (Sander \& Kõomägi, 2007; Festel et al., 2013; Goedhart et al., 2015; Dziwok, 2015).

In particular, Damodaran outlines his own DCF model to assess early-stage company values by making numerous adjustments that consider specific features of startups (Damodaran, 2009; 2014).

To assess cash flows, Damodaran overcomes the problem of lack of historical data by using two alternative methodologies: a top-down approach and a bottom-up approach. These approaches are based on analysis of the future (although uncertain) instead of the past.

The top-down approach can be broken down in the following steps (Damodaran, 2009; 2014): a) analysing the 
potential market for goods/services sold by the company, b) estimating potential market share that company would like to get in the future and the time required to achieve this objective, c) assessing operating margins (or costs) associated with provisional revenues linked to target market share, d) evaluating investments needed for growth, which means valuing how much the company has to invest to reach its objectives, e) computing the tax effect, and f) performing an internal consistency check. In this step, it is necessary to check that the estimated refinancing need is adequate.

The bottom-up approach is more simplistic than the top-down approach. It is similar to drawing up a budget, and the results depend largely on the quality of the forecasts of revenues and expected cash flows. It is more suitable to assess the value of companies that have relevant difficulties in raising capital or the success of which depends on one or a few key people. This approach includes the following steps (Damodaran, 2009): a) estimating the investment needed to support company growth, which also determines the production capacity, b) estimating sales during the considered time horizon, $\mathrm{c}$ ) estimating operating costs during the considered time horizon, d) estimating taxes, and e) estimating additional reinvestment to increase or maintain the business' earning capacity.

To estimate the discount rate to assess a startup's value, as outlined in a previous part of this article, traditional models are not adequate. Damodaran proposes the following measures to get a realistic discount rate (Damodaran, 2009; 2014):

- Focus on the specific business sector. The risk can be better estimated analysing the sector in which the company operates, especially considering the riskiness of listed companies operating in the same sector. The betas of these listed firms are used to arrive at an estimate of the market risk associated with being in this business.

$$
\beta \text { for the sector }{ }_{U n l e v e r e d}=\frac{\text { Average regression Beta for listed firms }}{\left(1+(1-\text { tax rate }) * \text { average market } \frac{D}{E} \text { ratio for sector }\right)}
$$

- Adjust the risk for diversification or its absence. The following formula expresses the beta for an undiversified investor (this beta is higher than market beta because it includes all risk to operate in only one business).

$$
\text { Total } \beta=\frac{\text { Market } \beta \text { publicly traded firms in business }}{\text { Correlation with the market } \text { publicly traded firms in business }}
$$

The firm gradually grows up and receives new funds from venture capitalists who have some diversification. The portfolio of investments held by a venture capitalist will be more highly correlated with the market than an individual company is, and the resulting total beta for a venture capitalist will be lower.

$$
\text { Total Bet } a_{V C}=\frac{\text { Market Bet } a_{\text {publicly traded firms in business }}}{\text { Correlation with the market } V C \text { Portfolio }}
$$

Ultimately, the cost of equity will converge on the market beta measure if the firm goes public or is sold to a publicly traded entity.

- $\quad$ Consider the use of debt and its cost.

- Look at management proclivities and industry averages.

- Build in expected changes in all of these inputs over time.

For the assessment of terminal value (TV), Damodaran (2009) suggests one of the following methods. The first one is to value the company as growing and make assumptions that cash flows will grow in perpetuity. The second method is to assume how long cash flow is expected to continue in a certain period and estimate the present value of these cash flows. Last, assume the company will be liquidated at the end of the forecast period and the salvage value of any assets accumulated over the company's life is the terminal value (Subroto \& Sukarno, 2019). The choice of one of the three above approaches depends on the features of the evaluated startup.

Another amendment introduced by Damodaran in his modified DCF model is adjusting for survival. This element is considered in two steps. In the first phase, the startup is valued assuming that it will survive in good financial health. In the second phase, the possibility that the startup will not survive is introduced, and the likelihood is estimated using sector average data (Knaup \& Piazza, 2007) or the probit approach or through simulation. Then, the startup's value is calculated as the present value of these two scenarios (growing scenario and default scenario). 
In addition, Damodaran introduced another new element: the key person discount. The success of early-stage companies often depends on the founder or a few key people. To assess a key person discount in valuations, it is suggested that the firm be first valued with the status quo (with key people involved in the business) and be valued again, with the loss of these individuals built into revenues, earnings and expected cash flows. The key person discount can be expressed in the following way:

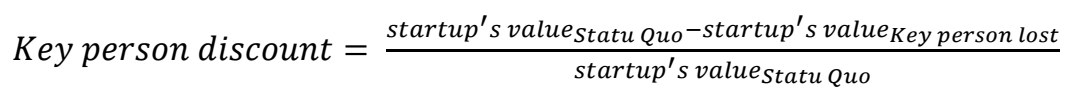

In addition to Damodaran's modified DCF method, other (less known) versions of modified DCF methods exist. Among them, the one discussed by Azka \& Faturohman (2020) should be noted.

\section{3 "Empirical" Methods for Startup Valuation Developed by Investors}

\subsubsection{The "Rule of Thirds"}

This method is often used by business angels to quickly value a startup. Given its simplicity and arbitrariness, the rule of thirds (RoT) is considered more of a "valuation screen" than a real valuation method (Mothersill et al., 2009).

Empirical experience shows that, generally, each startup sees the presence of three parties: the founders who had the business idea and contribute part of the equity, the external investors that contribute part of the equity, and the managers that manage the business and often get shares through stock option plans (created by shareholders to motivate managers and to direct results). In light of this evidence and imagining that each part has one-third of total capital, the result is the RoF, according to which during each funding round, the post-money value of a startup is equal to triple the equity offered by the investor.

\subsubsection{The Replacement Method and the Value Based Balance Sheet}

These methods descend directly from the cost approach.

The replacement method assesses a startup's value considering costs that should be incurred to recreate the same company at the same phase of the lifecycle (van de Schootbrugge \& Wong, 2013).

The value-based balance sheet method estimates a startup's value including the present value of the company's assets and liabilities, taking into account the firm's risk profile (Kallir \& Agmon, 2015).

As outlined previously, the main limitations of these methods are the failure to consider future perspectives and development opportunities for startups, which are the main elements driving a startup's value.

\subsubsection{The Berkus Method}

This method was created by Dave Berkus in 1996 and was cited first in Amis \& Stevenson (2001). Over time, this method was modified by both Berkus and other business angels. The Berkus method (BM) is suitable for a startup in a pre-revenue stage; it is appropriate to startups identified as likely to achieve 20 million dollars revenues by the fifth business year (Berkus, 2012).

The last version of the BM identifies five common risk factors for young companies. Each of them is assigned a financial valuation from 0 to $1 \frac{1}{2}$ million dollars (Berkus, 2016) (Table 1).

Table 1. Valuation of risk factors according to the Berkus Method (Berkus, 2016)

\begin{tabular}{lc}
\hline \multicolumn{1}{c}{ If Exists } & Add to company Value up to \\
\hline Sound Idea (basic value) & $\$ 1 / 2$ million \\
Prototype (reducing technology risk) & $\$ 1 / 2$ million \\
Quality Management Team (reducing execution risk) & $\$ 1 / 2$ million \\
Strategic relationships (reducing market risk) & $\$ 1 / 2$ million \\
Product Rollout or Sales (reducing production risk) & $\$ 1 / 2$ million \\
\hline
\end{tabular}

The maximum limit of $1 / 2$ million dollars for each risk factor means that the startup's estimated value cannot exceed 2.5 million dollars.

The last version of the BM is characterized by greater flexibility than the previous version, allowing the adopter 
to consider many specific risks. Moreover, it is possible to give a financial value higher than 500,000 dollars to each risk factor as long as it is adequate for that sector.

The BM is useful for focusing on some important factors affecting startup life and its chance of success (Payne, 2016). This method is considered a good complement to the Scorecard Method and to VCM (Kowlessar, 2016). However, the BM also has relevant limits, such as high subjectivity in the financial valuation of the five considered risk factors.

\subsubsection{The Scorecard Method}

This method was elaborated by a business angel named Bill Payne, and it is suitable for startup valuations in a pre-revenue stage. It allows compares the startup by assessing it with other young companies recently funded in the same geographical area. In particular, the scorecard method (SM) "corrects" the average value estimate of comparable firms to get a pre-money valuation of the target startup. The comparison is made only with companies that are in the same lifecycle (Payne, 2011b).

The application of this method consists of two steps. The first phase is to establish the average pre-money valuation of pre-revenue companies operating in the same geographical area and in the same business sector. The second phase is the comparison between the startup under assessment and comparable companies, with regard to some specific variables, to which the SM gives different weights (with a specific range) as indicated in Table 2 (Payne, 2011b).

Table 2. Valuation of variables according to the Scorecard Method (Payne, 2011b)

\begin{tabular}{lc}
\hline \multicolumn{1}{c}{ Factors } & Relative weight \\
\hline Strength of the Management Team & $0-30 \%$ \\
Size of the Opportunity (scalability) & $0-25 \%$ \\
Product/Technology & $0-15 \%$ \\
Competitive Environment & $0-10 \%$ \\
Marketing/Sales Channels/Partnerships & $0-10 \%$ \\
Need for Additional Investment & $0-5 \%$ \\
Other & $0-5 \%$ \\
\hline
\end{tabular}

The final value of a target startup is to multiply the sum of factors and the average startup's value (Achimská, 2020).

As in the BM, the SM focuses on very important aspects in assessing the startups' value, such as team management skills (Rose, 2014; Reverte et al., 2016). However, this method also has some weaknesses, such as great discretion used to assign a weight to different factors that determine the final startup value.

\subsubsection{The Risk Factor Summation Method}

This method was created by Ohio TechAngels (Rahardjo \& Sugiarto, 2019). In comparison with the scorecard and Berkus methods, the risk factor summation method (RFSM) considers a larger list of factors that are important for assessing a startup's value in a pre-revenue stage (Kowlessar, 2016). The RFSM includes different exogenous risk factors that a company should manage to get a profitable "exit" from the investment (Payne, 2011c).

The first step is the assessment of the average pre-money valuation of pre-revenue young companies operating in the same sector and geographical area (Karius, 2016). Then, the RFSM presents a list of possible risks associated with startups and their sectors (Payne, 2011c), such as management risk, stage of business, legislation/political risk, manufacturing risk, sales and marketing risk, funding/capital raising risk, competition risk, technology risk, litigation risk, international risk, reputation risk, and a potential lucrative exit. The weight of each risk has to vary according to the importance of this specific factor for the startup (Bratic et al., 2014). Each risk factor is assigned a different rating based on which will be the "correct" the average pre-money valuation for comparable companies. Table 3 summarizes these estimation parameters, their meaning and the adjustment that has to be applied to the average pre-money valuation of comparable young companies (Karius, 2016). 
Table 3. Risk Factor Summation: correction of average pre-money valuation for the sector

\begin{tabular}{clc}
\hline Rating & \multicolumn{1}{c}{ Meaning } & Average pre-money valuation adjustment \\
\hline 2 & Very positive to grow the business and get an ideal exit & $+\$ 500,000$ \\
1 & Positive & $+\$ 250,000$ \\
0 & Neutral & No correction \\
-1 & Negative & $-\$ 250,000$ \\
-2 & Very negative to grow the business and get an ideal exit & $-\$ 500,000$ \\
\hline
\end{tabular}

The RFSM expresses the startup's value according to this formula (Kowlessar, 2016):

$$
\text { pre-money valuation = average pre-money valuation for the sector }+/ \text { - adjustment }
$$

Similar to the Berkus method, it shows the signs of subjective evaluation but the perception of risks is more precise. Its main disadvantage is the fact that the method is market-oriented. Determination of the average pre-money value of a startup mirrors the situation in the sector and in the same geographical area. Moreover, another problem can be the shortage of information related to the region to derive this value (Achimská, 2020).

\subsection{The Automatic Web Valuators}

In recent years, different websites have been created that allow free (or partially free) startup valuation.

In most cases, it is enough to answer questions to get an approximate assessment of the startup's value. These automatic web valuators consider mainly qualitative information, and they offer a pre-money valuation. The main limits are excessive simplification and standardization of the evaluative process. Indeed, especially in startup valuation, it is very important to pay attention to specific features of the startup. Therefore, automatic web valuators can be considered more of a control instrument to support other estimate methodologies (Payne, 2011d).

Among the various automatic web valuators, please note the Cayenne calculator (Note 2), the Equidam calculator (Note 3), the Equitynet calculator (Note 4) and the Startuplawtalk calculator (Note 5).

\section{Results}

From the systematic review of the academic literature and professional practice in this conceptual article, it is possible to extract the following results.

First, it is clear that traditional valuation methods are inadequate for assessing a startup's value. The scarcity (often total absence) of historical data is an impassable problem that makes traditional valuation methods inappropriate.

In light of this situation, the academic literature tried to find innovative, alternative methods to traditional ones. Therefore, new valuation methods were born as the real option method (ROM), the venture capital method (VCM), the first Chicago method (FCM) and the modified DCF method (MDCFM).

Over time, considering the empirical evidence and experience in the field, investors, business angels and experts in valuation developed new methods to assess a startup's value. In addition to simplistic methods such as the rule of thirds, the replacement method and the value-based balance sheet method, successful business angels such as Bill Payne and Dave Berkus created more elaborate methodologies such as the scorecard method (SM) and the Berkus method (BM). The latter methods inspired other methods, such as the risk factor summation method. These approaches created by experts and investors take into account qualitative aspects, with a particular focus on critical factors that can determine the success or failure of the young company (Köhn, 2018; Mirzanti et al., 2019). Then, these qualitative variables are transposed to a quantitative dimension in their economic evaluation to get the final startup value.

In the end, in recent years, websites with an automatic startup valuator were created. They present many questions and estimate a startup's value based on the answers.

This analysis creates an outline of the innovative methods examined and presents some critical issues, but they are more adequate for assessing a startup's value than traditional methods. The methods such as the ROM, VCM and FCM have very complex evaluation procedures, especially for assessing a correct discount rate or identifying appropriate multiples of comparable firms. The methods created by investors such as the scorecard method, the Berkus method and the RFSM pay more attention to qualitative factors that are important for the 
startup, but the valorisation of these qualitative factors is made by coefficients that are subjective and arbitrary. Because of the standardization of the evaluative process and the use of arbitrary coefficients, online automatic valuators are more useful as a support instrument than as real valuation methods.

The state of art exposed herein demonstrates a composite framework and suggests that, currently, there is no "perfect" valuation method for startups and that there is extensive room for improvement. The aim of a valuation method, especially in the case of a startup, is not to eliminate uncertainty (that is impossible), but to represent the startup's value in the best way by considering the specific characteristics of the startup under analysis.

This study helps us understand the current trend in startup valuation methods, i.e., the progressive abandonment of inaccurate and arbitrary approaches, preferring those built on the following key determinants:

- $\quad$ attention to future forecasts, instead of past data,

- using probability to consider different scenarios,

- understanding of and attention to the specific business model of a startup rather than data on comparable companies in the market.

Indeed, valuation methods that consider probability-adjusted or risk-adjusted forecasts present a more refined analysis of expected future events, and thus, a more refined estimate of enterprise value (Halt et al., 2017).

The academic literature and experts are invited to develop valuation methods that adequately consider and harmonise the three features just mentioned, which are considered the most important variables to achieve a reliable startup valuation.

\section{Discussion and Future Research}

In today's economy, startup companies are very important actors. Startups contribute dramatically in terms of economic value (Stangler, 2019), technology innovation (Choi et al., 2020) and job creation (Calvino et al., 2016).

Therefore, taking into consideration the spread and the importance of the economy for startups, it is important to have correct methods to measure their value.

Because of the particular features of early-stage companies, it is not easy to find an adequate method to assess their value. Startup valuation is often said to be more art than science (Köhn, 2018). Traditional valuation methods (cost approach, income approach and market approach) are unsuitable for startups. Therefore, over time, the academic literature and experienced investors created alternative and innovative valuation models for these kinds of companies.

With this conceptual paper, we provided a systematic literature review about the main innovative methods, outlining the advantages and limits of each. In particular, we analysed the real option method, the venture capital method, the first Chicago method, the modified DCF method and methods developed directly by experienced investors or practitioners, such as the rule of thirds, the replacement method, the value-based balance sheet, the Berkus method, the scorecard method, the risk factor summation method and the automatic web valuator created to assess startup value.

The results showed that there is currently no "perfect" method to assess startup value. Each analysed model has significant limits, and the possibilities for improvements are many. We are witnessing a gradual withdrawal from more arbitrary valuation models, and consciousness is growing that to better assess startup value, it is necessary to consider three aspects: attention to future forecasts instead of past data, using probability to consider different scenarios, an understanding and paying attention to the specific business model of a startup rather than data on comparable companies in the market. Today, none of the discussed methods integrates these three features harmoniously.

In the light of this evidence, we expect that in the near future, the academic literature will develop new valuation methods (or will perfect existing ones) that should consider the three characteristics mentioned previously. In this way, it would be possible to create a more suitable method for assessing startup value, a method to reduce uncertainty and that better represents startup value, making startup valuation more reliable.

\section{References}

Achimská, V. (2020). Start-ups, bearers of innovation in globalizing environment and their valuation. In SHS Web of Conferences (Vol. 74, p. 01001). EDP Sciences. https://doi.org/10.1051/shsconf/20207401001

Achleitner, A. K., \& Lutz, E. (2005). First Chicago Method: Alternative Approach to Valuing Innovative Start-Ups in the Context of Venture Capital Financing Rounds (First-Chicago-Methode-Alternativer Ansatz 
zur Bewertung von innovativen Unternehmensgründungen bei Venture-Capital-Finanzierungen). Betriebswirtschaftliche Forschung und Praxis (BFuP), 57(4), 333-347. Retrieved from https://ssrn.com/abstract=1133004

Akkaya, M. (2020). Startup Valuation: Theories, Models, and Future. In Valuation Challenges and Solutions in Contemporary Businesses (pp. 137-156). IGI Global. https://doi.org/10.4018/978-1-7998-1086-5.ch008

Amis, D., \& Stevenson, H. H. (2001). Winning angels: the seven fundamentals of early-stage investing.

Amit, R., Glosten, L., \& Muller, E. (1990). Entrepreneurial ability, venture investments, and risk sharing. Management science, 36(10), 1233-1246. https://doi.org/10.1287/mnsc.36.10.1233

Andalib, M. S., Tavakolan, M., \& Gatmiri, B. (2018). Modeling managerial behavior in real options valuation for project-based environments. International Journal of Project Management, 36(4), 600-611. https://doi.org/10.1016/j.ijproman.2018.02.001

Azka, G. R., \& Faturohman, T. (2020). Internal Startup Valuation of PT Telekomunikasi Indonesia, Tbk by applying Risk-based New Venture Valuation Technique (Case Study: Company V). European Journal of Business and Management Research, 5(1). https://doi.org/10.24018/ejbmr.2020.5.1.214

Babiarz, A. (2016). Methods of valuing investment projects used by Venture Capital funds, financed from public funds. Prace Naukowe Uniwersytetu Ekonomicznego we Wrocławiu, 428, 11-28. https://doi.org/10.15611/pn.2016.428.01

Beaton, N. J. (2010). Valuing early stage and venture-backed companies (Vol. 503). John Wiley \& Sons.

Berkus, D. (2012). The Berkus Method-Valuing the Early Stage Investment. Berkonomics. Retrieved from https://berkonomics.com/?p=1214

Berkus, D. (2016). After 20 years: Updating the Berkus Method of valuation. Berkonomics. Retrieved from https://berkonomics.com/?p=2752

Bhagat, S. (2014). Why do venture capitalists use such high discount rates? The Journal of Risk Finance. https://doi.org/10.1108/JRF-08-2013-0055

Birley, S., \& Westhead, P. (1994). A taxonomy of business start-up reasons and their impact on firm growth and size. Journal of business venturing, 9(1), 7-31. https://doi.org/10.1016/0883-9026(94)90024-8

Black, E. (2003). Usefulness of financial statement components in valuation: an examination of start-up and growth firms. Venture Capital: An International Journal of Entrepreneurial Finance, 5(1), 47-69. https://doi.org/10.1080/136910603200006722

Black, F., \& Scholes, M. (1973). The pricing of options and corporate liabilities. Journal of political economy, 81(3), 637-654. https://doi.org/10.1086/260062

Blank, S. (2020). The startup owner's manual: The step-by-step guide for building a great company. John Wiley \& Sons.

Bratic, W., Blok, J. R., \& Gostola, M. M. (2014). Valuation of early-stage companies in the biotechnology industry. Journal of Commercial Biotechnology, 20(2). https://doi.org/10.5912/jcb648

Calvino, F., Criscuolo, C., \& Menon, C. (2016). No Country for Young Firms?: Start-up Dynamics and National Policies. OECD Science, Technology and Industry Policy Papers, No. 29, OECD Publishing, Paris. https://doi.org/10.1787/5jm22p40c8mw-en

Choi, D. S., Sung, C. S., \& Park, J. Y. (2020). How Does Technology Startups Increase Innovative Performance? The Study of Technology Startups on Innovation Focusing on Employment Change in Korea. Sustainability, 12(2), 551. https://doi.org/10.3390/su12020551

Cong, L. W. (2017). Real options, business valuation, and dynamic decisions. Journal of Management Policy and Practice, 18(3). https://doi.org/10.33423/jmpp.v18i3.1706

Damodaran, A. (2009). Valuing Young, Start-Up and Growth Companies: Estimation Issues and Valuation Challenges, June 12, 2009. Available at SSRN: http://ssrn. com/abstract (Vol. 1418687). https://doi.org/10.2139/ssrn.1418687

Damodaran, A. (2014). Valuing Start-Ups. In QFinance: The Ultimate Resource. Bloomsbury Publishing.

Damodaran, A. (2016). Damodaran on valuation: security analysis for investment and corporate finance (Vol. 324). John Wiley \& Sons. 
Davila, A., \& Foster, G. (2005). Management accounting systems adoption decisions: evidence and performance implications from early-stage/startup companies. The Accounting Review, 80(4), 1039-1068. https://doi.org/10.2308/accr.2005.80.4.1039

de Oliveira, F. B., \& Zotes, L. P. (2018). Valuation methodologies for business startups: a bibliographical study and survey. Brazilian Journal of Operations \& Production Management, 15(1), 96-111. https://doi.org/10.14488/BJOPM.2018.v15.n1.a9

Dehghan-Eshratabad, M., \& Albadvi, A. (2018). Applying real option approach for startup valuation by venture capitalists in first round of financing. Management Research in Iran, 22(3), 1-27. Retrieved from http://journals.modares.ac.ir/article-19-28089-en.html

Demyanova, E. A. (2018). Current issues of company evaluation under fintech. Strategic decisions and risk management, 1, 102-117. https://doi.org/10.17747/2078-8886-2018-1-102-1

Dusatkova, M. S., \& Zinecker, M. (2016). Valuing start-ups-selected approaches and their modification based on external factors. Business: Theory and Practice, 17, 335. https://doi.org/10.3846/btp.17.11129

Dziwok, E. (2015). Sensitivity analysis of IPO valuation for start-up companies. 10th International Scientific Conference Financial management of Firms and Financial Institutions, Ostrava VSB-TU of Ostrava, Faculty of Economics, Department of Finance. Retrieved from https://www.researchgate.net/profile/Ewa_Dziwok/publication/320357272_Sensitivity_analysis_of_IPO_va luation_for_start-up_companies/links/5a31239c0f7e9bf8992d1019/Sensitivity-analysis-of-IPO-valuation-fo r-start-up-companies.pdf

Fazekas, B., \& Becsky-Nagy, P. (2015). The role of venture capital in the bridging of funding gaps-A real options reasoning. Annals of Faculty of Economics, 1(1), 825-830. Retrieved from https://core.ac.uk/download/pdf/161056068.pdf

Fernández, P. (2007). Company valuation methods. The most common errors in valuations. IESE Business School, 449. https://doi.org/10.2139/ssrn.1025424

Festel, G., Wuermseher, M., \& Cattaneo, G. (2013). Valuation of early stage high-tech start-up companies. International Journal of Business, 18(3), 216. Retrieved from https://www.craig.csufresno.edu/ijb/Volumes/Volume\%2018/V183-3.pdf

Fink, A. (2019). Conducting research literature reviews: From the internet to paper. Sage publications.

Flöstrand, P., \& Ström, N. (2006). The valuation relevance of non - financial information. Management Research News. https://doi.org/10.1108/01409170610709014

Frykman, D., \& Tolleryd, J. (2012). The Financial Times Guide to Corporate Valuation. Pearson UK.

Ge, D., Mahoney, J. M., \& Mahoney, J. T. (2005). New venture valuation by venture capitalists: An integrative approach. University of Illinois at Urban Champaign Working Paper, 124, 05-0124. Retrieved from https://EconPapers.repec.org/RePEc:ecl:illbus:05-0124

Goedhart, M., Koller, T., \& Wessels, D. (2015). Valuation: Measuring and managing the value of companies. JohnWiley \& Sons.

Goldenberg, D. H., \& Goldenberg, M. D. (2009). Why entrepreneurs and VCs disagree in valuing start-up firms: imputing the target rate of return using DCF vs. option-based approaches. The Journal of Private Equity, 13(1), 73-79. https://doi.org/10.3905/JPE.2009.13.1.073

Goldman, M. (2008). Valuation of startup and early-stage companies. A Profissional Development Journal for the Consulting Disciplines, 8-16. Retrieved from http://www.michaelgoldman.com/Publications/Goldman\%20Valuation\%20of\%20Start-ups.pdf

Granlund, M., \& Taipaleenmäki, J. (2005). Management control and controllership in new economy firms-a life cycle perspective. Management Accounting Research, 16(1), 21-57. https://doi.org/10.1016/j.mar.2004.09.003

Gummerus, J. (2013). Value creation processes and value outcomes in marketing theory: strangers or siblings? Marketing theory, 13(1), 19-46. https://doi.org/10.1177/1470593112467267

Halt, G. B., Donch, J. C., Stiles, A. R., \& Fesnak, R. (2017). Valuing Startup Companies. In Intellectual Property and Financing Strategies for Technology Startups (pp. 205-218). Springer, Cham. https://doi.org/10.1007/978-3-319-49217-9_16 
Hashemi S. (2015). Venture Valuation - First Chicago Method. Venionaire Capital. Retrieved from https://www.venionaire.com/first-chicago-method-valuation/

Ho, H., Jeong, S. B., \& Lee, B. G. (2016, December). Conceptual Framework for Startup Enterprise Evaluation: Value of the Trust and Soft Information. In 2016 3rd Asia-Pacific World Congress on Computer Science and Engineering (APWC on CSE) (pp. 181-186). IEEE. https://doi.org/10.1109/APWC-on-CSE.2016.038.

Hoseini, S. A., \& Moradi Esfanjani, H. (2019). Designing a Valuation Model for Petroleum Startups. International Journal of Finance \& Managerial Accounting, 3(12), 95-107. Retrieved from http://ijfma.srbiau.ac.ir/article_14029.html

Houben, E. (2002). Venture capital, double-sided adverse selection, and double-sided moral hazard. Double-Sided Adverse Selection, and Double-Sided Moral Hazard (December 2002). https://doi.org/10.2139/ssrn.314002

IVSC. (2012). Technical Information Paper 1: Discounted Cash Flow. IVSC Publishing, Londra.

Kallir, I., \& Agmon, T. (2015). Valuating the Value and Risk of International Start-up Ventures. International Journal of Financial Research, 6(2), 203-217. https://doi.org/10.5430/ijfr.v6n2p203

Karius, T. (2016). Intellectual property and intangible assets: Alternative valuation and financing approaches for the knowledge economy in Luxembourg (No. 3). EIKV-Schriftenreihe zum Wissens-und Wertemanagement. Retrieved from http://hdl.handle.net/10419/126183

Keeley, R. H., Punjabi, S., \& Turki, L. (1996). Valuation of early-stage ventures: option valuation models vs. traditional approaches. The Journal of Entrepreneurial Finance, 5(2), 115-138. https://digitalcommons.pepperdine.edu/jef/vol5/iss $2 / 3$

Knaup, A. E., \& Piazza, M. C. (2007). Business employment dynamics data: survival and longevity, II. Monthly Lab. Rev., 130, 3. Retrieved from: https://stats.bls.gov/opub/mlr/2007/09/art1full.pdf

Köhn, A. (2018). The determinants of startup valuation in the venture capital context: a systematic review and avenues for future research. Management Review Quarterly, 68(1), 3-36. https://doi.org/10.1007/s11301-017-0131-5

Koller, T., Goedhart, M., \& Wessels, D. (2010). Valuation: measuring and managing the value of companies (Vol. 499). john Wiley and sons.

Kollmann, T., Stöckmann, C., Hensellek, S., \& Kensbock, J. (2016). European startup monitor 2016. Universität Duisburg-Essen Lehrstuhl für E-Business.

Kolvereid, L., \& Isaksen, E. (2006). New business start-up and subsequent entry into self-employment. Journal of business venturing, 21(6), 866-885. https://doi.org/10.1016/j.jbusvent.2005.06.008

Kowlessar F. A. (2016). The Berkus \& Risk Factor Summation Pre-Money Valuation Methods Explained. Retrieved from https://magazine.startus.cc/berkus-risk-factor-summation-pre-money-valuationmethods-explained

Krishna, A., Agrawal, A., \& Choudhary, A. (2016, December). Predicting the outcome of startups: less failure, more success. In 2016 IEEE 16th International Conference on Data Mining Workshops (ICDMW) (pp. 798-805). IEEE. https://doi.org/10.1109/ICDMW.2016.0118

Laitinen, E. K. (2019). Discounted Cash Flow (DCF) as a Measure of Startup Financial Success. Theoretical Economics Letters, 9(08), 2997. https://doi.org/10.4236/tel.2019.98185

Littell, J. H., Corcoran, J., \& Pillai, V. (2008). Systematic reviews and meta-analysis. Oxford University Press. https://doi.org/10.1093/acprof:oso/9780195326543.001.0001

Majercakova, D., \& Mittelman, A. (2018). The analysis of the chosen methods of the evaluation of start-ups on the specific case. Economic and Social Development: Book of Proceedings, 484-490.

Mate, M., \& Occhino, P. (2020). A proposal to estimate the valuation of small and medium size companies using geographically comparable information. Small Business International Review, 4(1), 34-51. https://doi.org/10.26784/sbir.v4i1.229

Mathews, S. (2009). Valuing risky projects with real options. Research-Technology Management, 52(5), 32-41. https://doi.org/10.1080/08956308.2009.11657587

Milanesi, G. S., Pesce, G., \& El Alabi, E. (2013). Technology-based startup valuation using real options with Edgeworth expansion. Retrieved from http://repositoriodigital.uns.edu.ar/handle/123456789/4264 
Miloud, T., Aspelund, A., \& Cabrol, M. (2012). Startup valuation by venture capitalists: an empirical study. Venture Capital, 14(2-3), 151-174. https://doi.org/10.1080/13691066.2012.667907

Mirzanti, I. R., Sinaga, E. E. M., \& Soekarno, S. (2019). Determinant factors in digital start-up valuation for agro seed funding. International Journal of Agricultural Resources, Governance and Ecology, 15(4), 338-357. https://doi.org/10.1504/IJARGE.2019.104202

Montani, D., Perrini, F., Gervasio, D., \& Pulcini, A. (2018). The Importance of "Contextualisation" in Small and Medium-Sized Firms Valuation: Evidences from an Italian Case Study. International Journal of Business and Management, 13(1), 70. https://doi.org/10.5539/ijbm.v13n1p70

Mothersill, W. D., Watson, B., Fast, F., \& Gedeon, S. (2009). Age Of The Angel: Best Practices For Angel Groups. National Angel Organization, Canada.

Nofsinger, J. R., \& Wang, W. (2011). Determinants of start-up firm external financing worldwide. Journal of Banking \& Finance, 35(9), 2282-2294. https://doi.org/10.1016/j.jbankfin.2011.01.024

Payne, B. (2011a). Valuations 101: The Venture Capital Method. Retrieved from http://blog.gust.com/startup-valuations-101-the-venture-capital-method/

Payne, B. (2011b). Scorecard Valuation Methodology. Establishing the Valuation of Prerevenue, Startup Companies. Retrieved from https://www.semanticscholar.org/paper/SCORECARD-VALUATION-METHODOLOGY-Establishing-theof-Payne/e97709f963bf19d548d9e7dc8fdb30610717dae6

Payne, B. (2011c). Valuations 101: The Risk Factor Summation Method. Retrieved from http://blog.gust.com/valuations-101-the-risk-factor-summation-method/

Payne, B. (2011d). Valuations 101: The Cayenne Calculator. Retrieved from http://blog.gust.com/startup-valuations-101-the-cayenne-calculator/

Payne, B. (2016). Valuations 101: The Dave Berkus Method. Retrieved from http://blog.gust.com/248/

Pepis, S., Evans, J., \& de Jong, P. (2018). The Valuation of Startups in New Markets: an Applied Case in Asteroid Mining. International Journal of Business and Social Science, 9(4). Retrieved from http://www.ijbssnet.com/journals/Vol_9_No_4_April_2018/2.pdf

Rahardjo, D., \& Sugiarto, M. (2019, March). Valuation model using a mixed real options method: a review on Singapore and Indonesia digital startups. In 16th International Symposium on Management (INSYMA 2019). Atlantis Press. https://doi.org/10.2991/insyma-19.2019.3

Reis, P., \& Augusto, M. (2013). The terminal value (TV) performing in firm valuation: The gap of literature and research agenda. Journal of Modern Accounting and Auditing, 9(12), 1622-1636. Retrieved from http://hdl.handle.net/10400.19/3621

Reverte, C., Sánchez-Hernández, M. D. M., \& Rojo-Ramírez, A. (2016). The profile of venture capital investments: the European context. International Journal of Business and Globalisation, 17(1), 83-110. https://doi.org/10.1504/IJBG.2016.077568

Rose, D. S. (2014). Angel investing: The gust guide to making money and having fun investing in startups. John Wiley \& Sons.

Sahlman, W. A., \& Scherlis, D. R. (1987). A Method For Valuing High-Risk, Long-Term Investments: The" Venture Capital Method". Retrieved from https://www.hbs.edu/faculty/Pages/item.aspx?num=6515

Sammut, S. M. (2012). Valuation Methods in Early-Stage Biotechnology Enterprises: The" Venture Capital Method" at Work. Journal of Commercial Biotechnology, 18(2). https://doi.org/10.5912/jcb494

Sander, P., \& Kõomägi, M. (2007). Valuation of private companies by Estonian private equity and venture capitalists. Baltic Journal of Management. https://doi.org/10.1108/17465260710720219

Schmidlin, N. (2014). The art of company valuation and financial statement analysis: a value investor's guide with real-life case studies. John Wiley \& Sons.

Shestakov, D. (2015). Real Option Approach to Evaluate Strategic Flexibility for Startup Projects. In Business and Economics Conference: Volume 3 (Vol. 1, p. 2). https://doi.org/10.5038/2372-5885-v3

Shevlin, T. (1996). The value-relevance of nonfinancial information: A discussion. Journal of Accounting and Economics, 22(1-3), 31-42. https://doi.org/10.1016/S0165-4101(96)00441-7 
Sievers, S., Mokwa, C. F., \& Keienburg, G. (2013). The relevance of financial versus non-financial information for the valuation of venture capital-backed firms. European Accounting Review, 22(3), 467-511. https://doi.org/10.1080/09638180.2012.741051

Smit, H. T., \& Trigeorgis, L. (2012). Strategic investment: Real options and games. Princeton University Press. https://doi.org/10.2307/j.ctvem4hg0

Smith, J., Smith, R. L., Smith, R., \& Bliss, R. (2011). Entrepreneurial finance: strategy, valuation, and deal structure. Stanford University Press. https://doi.org/10.1515/9780804777582

Stangler, D. (2019). The global Startup Economy is growing, but who is left out? Forbes, 09.05.2019. Retrieved from

https://www.forbes.com/sites/danestangler/2019/05/09/the-global-startup-economy-is-growing-but-who-is-1 eft-out/\#394286bc5e16

Stankevičienè, J., \& Žinytė, S. (2011). Valuation model of new start-up companies: Lithuanian case. Business: Theory and Practice, 12(4), 379-389. https://doi.org/10.3846/btp.2011.39

Steffens, P., \& Douglas, E. (2007). Valuing technology investments: use real options thinking but forget real options valuation. International Journal of Technoentrepreneurship, 1(1), 58-77. https://doi.org/10.1504/IJTE.2007.013270

Subroto, C. G., \& Sukarno, S. (2019). Start-Up Valuation for Internal Corporate Venture of PT Telekomunikasi Indonesia Tbk (Case Study: Venture B). European Journal of Business and Management Research, 4(5). https://doi.org/10.24018/ejbmr.2019.4.5.98

van de Schootbrugge, E., \& Wong, K. M. (2013). Multi-Stage Valuation for Start-Up High Tech Projects and Companies. Journal of Accounting and Finance, 13(2), 45-56. Retrieved from http://www.na-businesspress.com/JAF/WongKM_Web13_2_.pdf

Visconti, R. M. (2020). The Valuation of Technological Startups. In The Valuation of Digital Intangibles (pp. 155-192). Palgrave Macmillan, Cham. https://doi.org/10.1007/978-3-030-36918-7

Wardani, I. S., \& Fujiwara, T. (2018). Applying a Two-Stage Option Games Method to Investment Decisions of Business Startups: Case Study of a Smart House Startup in Indonesia. Asian Journal of Innovation and Policy, 7(1), 178-189.

\section{Notes}

Note 1 . The pre-money value shows the company's valuation before the investors provide funding, while the post-money value shows the company's value after investors provide funding (Frykman \& Tolleryd, 2012).

Note 2. The automatic calculator was retrieved from https://www.caycon.com/valuation

Note 3. The automatic calculator was retrieved from https://www.equidam.com

Note 4. The automatic calculator was retrieved from https://www.equitynet.com/crowdfunding-tools/startup-valuation-calculator.aspx

Note 5. The automatic calculator was retrieved from https://www.startuplawtalk.com/startup-company-valuation-and-dilution-calculator/

\section{Copyrights}

Copyright for this article is retained by the author(s), with first publication rights granted to the journal.

This is an open-access article distributed under the terms and conditions of the Creative Commons Attribution license (http://creativecommons.org/licenses/by/4.0/). 